\title{
RADIOCARBON DATING OF FOURTEEN DEAD SEA SCROLLS
}

\author{
GEORGES BONANI ${ }^{1}$, SUSAN IVY', WILLY WÖLFLI ${ }^{1}$, MAGEN BROSHI ${ }^{2}$, ISRAEL CARMI ${ }^{3}$ \\ and JOHN STRUGNELL4
}

\begin{abstract}
The name Dead Sea Scrolls refers to some 1200 manuscripts found in caves in the hills on the western shore of the Dead Sea during the last 45 years. They range in size from small fragments to complete books from the holy scriptures (the Old Testament). The manuscripts also include uncanonized sectarian books, letters and commercial documents, written on papyrus and parchment. In only a few cases, direct information on the date of writing was found in the scrolls. In all other cases, the dating is based on indirect archaeological and paleographical evidence. To check this evidence, radiocarbon ages of 14 selected scrolls were determined using accelerator mass spectrometry. The calibrated radiocarbon ages agree well, except in one case, with the paleographic estimates or the specific dates noted on the scrolls.
\end{abstract}

\section{INTRODUCTION}

The first Dead Sea Scrolls were discovered accidentally by a Bedouin shepherd in a cave near Khirbet Qumran in 1947. In that cave alone, approximately 800 texts written in Hebrew and Aramaic on papyri and parchments were finally excavated (Benoit, Milik \& de Vaux 1961). Sukenik (1948) concluded that the manuscripts should be ascribed to the Essenes. Archaeological evidence indicates that the Essenes, one of the three major religious movements of Judaism at that time, settled this site around $100 \mathrm{BC}$. They abandoned it in AD 68, apparently upon its conquest by the Roman army during the Jewish revolt. The manuscripts from this site can be divided into Biblical and Sectarian texts. The former comprises 23 out of the 24 known books of the Old Testament. The latter consists of religious writings and business transactions of the Essenes. Following this discovery, more scrolls were found in additional sites located west and northwest of the Dead Sea (Fig. 1). Although the manuscripts from the Qumran site are the Dead Sea Scrolls sensu stricto, this name is now applied to all of the ca. 1200 manuscripts found to date in this region (Broshi 1990).

None of the 800 Qumran manuscripts bears the date of its copying, and only two have an internal terminus a quo (Milik 1959). In contrast, manuscripts found in other Judean Desert sites bear specific dates. For non-date-bearing scrolls, indirect archaeological evidence, such as pottery or coins, can be used to estimate the terminus ad quem. Paleography, the study of ancient writings, is often a more accurate method of dating. The history of Jewish scripts can be delineated in great detail, and paleographers are able to ascribe dates in the range of half, or even a quarter, century (Avigad 1958; Cross 1961; Birnbaum 1971). In the decades following the initial discovery of the scrolls, however, a number of scholars began to challenge the paleographic datings, a debate that continues up to the present (Eisenman 1983). For this reason, we felt it was necessary to check on the paleographically determined ages by using an independent method. We present here the results of the first dating of 14 scrolls using the radiocarbon method.

\section{Previous Radiocarbon Dates}

Although the radiocarbon method was developed at approximately the same time that the scrolls were discovered, too much disposable material (several grams) was required for dating. Only relat-

\footnotetext{
${ }^{1}$ Institut für Mittelenergiephysik, ETH-Hönggerberg, CH-8093 Zürich, Switzerland

${ }^{2}$ Israel Museum, 9710 Jerusalem, Israel

${ }^{3}$ Department of Environmental Sciences and Energy Research, Weizmann Institute of Science, 76100 Rehovot, Israel

${ }^{4}$ Divinity School, Harvard University, Cambridge, Massachusetts 02138 USA
} 


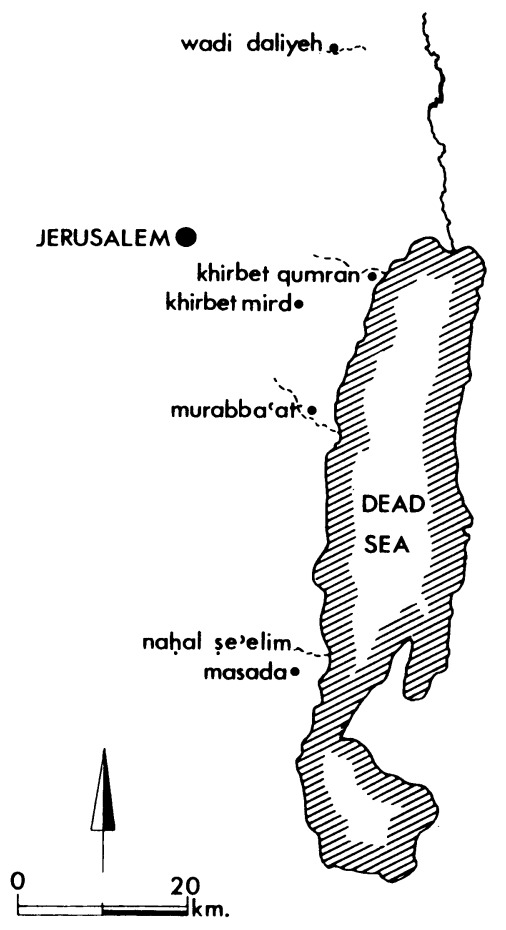

Fig. 1. Map of the Dead Sea region and sites where the dated scrolls were discovered. Reprinted by permission of 'Atiqot; courtesy of Israel Antiquities Authority.

ed material from the Qumran site was dated. Libby (1951) dated the linen wrapping of a scroll. He determined a value of $1917 \pm 200$ BP (conventional radiocarbon years), indicating that the corresponding scroll might be at least 2 ka old. In 1956 and 1960, Zeuner (1969) dated pieces of charred date palm logs excavated at the Qumran site and obtained $1940 \pm 85$ and $1965 \pm 85 \mathrm{BP}$. Dating of material from the scrolls, themselves, became feasible only after the invention of accelerator mass spectrometry (AMS) (Suter et al. 1984; Wölfli 1987). With AMS, samples containing $0.5-1.0 \mathrm{mg}$ of carbon can now be dated with an accuracy comparable to that of the decay-counting method (Bonani et al. 1987).

\section{SELECTION AND SAMPLING OF THE SCROLLS}

Initial sampling of the scrolls took place on 7 July, 1990 at the Rockefeller and Israel Museums in Jerusalem. Table 1 lists the 14 scrolls finally selected for dating. A total of 20 samples (in some cases up to 3 samples from different parts of a particular scroll) were taken, photographed and weighed. Scrolls 1, 12, 13 and 14 are date-bearing documents. They span 1096 years, and were used to test the ${ }^{14} \mathrm{C}$ method. Detailed information on the content of the selected scrolls is in Bonani et al. (1991).

\section{SAMPLE PREPARATION}

In the laboratory, the authenticity of each sample was verified by comparison with photos taken at the sampling in Israel. The samples were reweighed and recoded. Each sample was split into subsamples, which were divided into two sets. The first set was treated and measured immediately. Treatment of the second set was deferred until the radiocarbon measurement of the first set had been completed. Three types of samples were dated: parchment, papyrus and linen threads that 


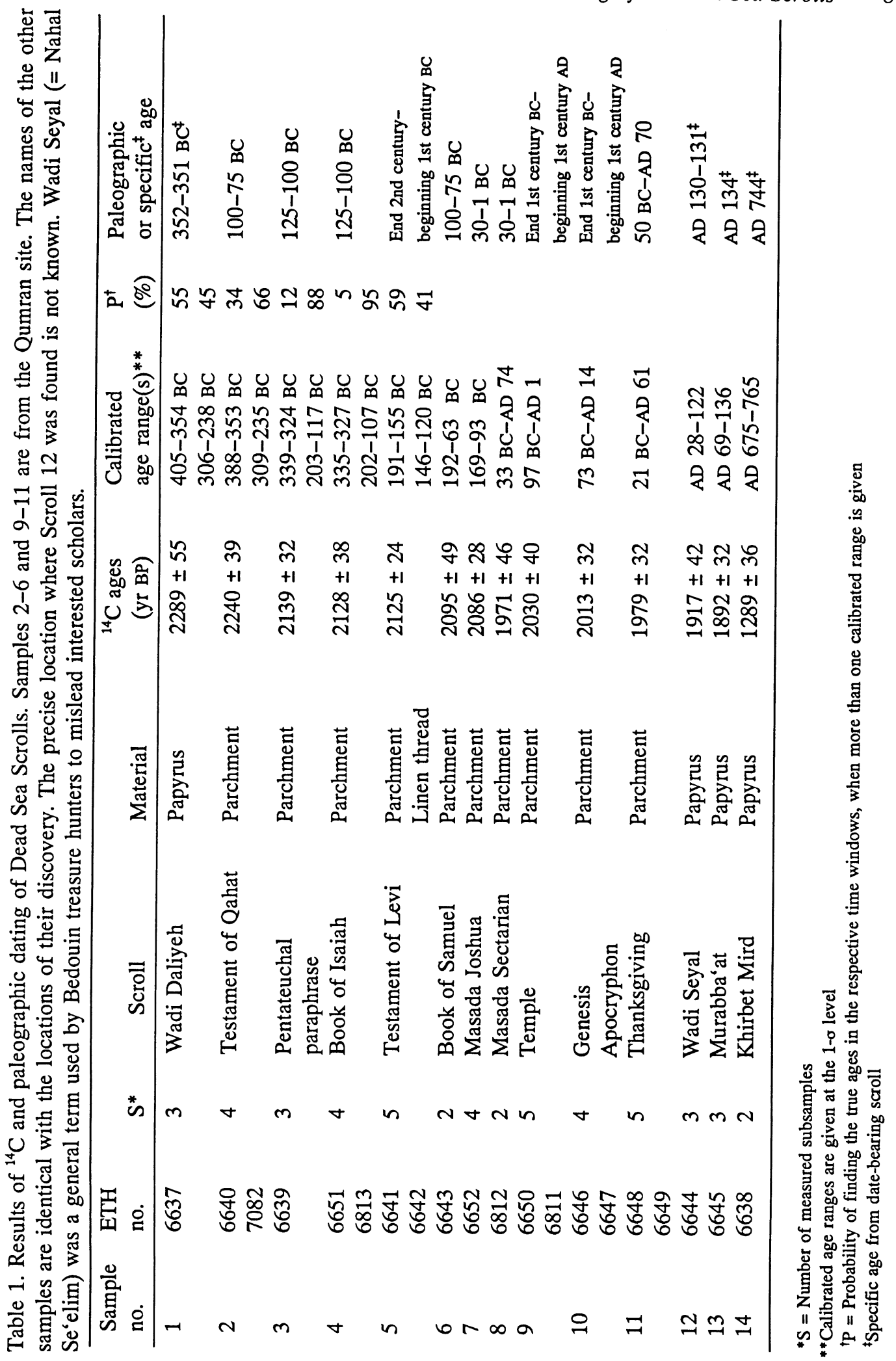


were attached to Sample 5, the Testament of Levi. All sample material was microscopically examined to identify and remove any foreign material, and to evaluate the condition of the parchment.

For chemical pretreatment of the samples, we followed the standard acid-base-acid steps (see, e.g., Damon et al. 1989). The samples were first treated in an ultrasonic bath. This was followed by hot acid, base, then acid treatments. The material was rinsed to $\mathrm{pH} 7$ with distilled water between the steps. The strength of the solution, temperature and length of time of each step depended on the ability of the material to withstand the treatment. For every sample, one subsample was only ultrasonically cleaned, whereas another subsample was ultrasonically and chemically cleaned. This was done to assess the removal of contaminants of each type of treatment. The samples were weighed before and after the cleaning procedures to determine the weight losses resulting from each step.

Parchment samples were affected by two complications; gelatinization (Samples 9, 10 and 11) and attachment of rice paper with glue, which had been used to reinforce scrolls in poor condition (Samples 4, 5, 7, 9 and 10). Microscopic examination revealed various degrees of gelatinization, estimated by darkening of the parchment from beige, when fresh, to dark brown and translucent, when extensively gelatinized. Gelatinization is described as the unfolding of the collagen structure to form gelatin (Weiner et al. 1980). This results in degradation and increased solubility of the parchment. Trial cleanings with pieces of extensively gelatinized parchment showed that most of the material had dissolved after our regular "strong" treatment $(0.5 \mathrm{M} \mathrm{HCl}, 0.1 \mathrm{M} \mathrm{NaOH}$ and 0.5 $\mathrm{M} \mathrm{HCl})$, as well as with one-half and one-fifth strength treatments. Thus one-tenth strength $(0.05$ $\mathrm{M} \mathrm{HCl}, 0.01 \mathrm{M} \mathrm{NaOH}$ and $0.05 \mathrm{M} \mathrm{HCl}$ ) was used to treat all parchment samples (1st and 2 nd set). Each step lasted 15-60 minutes, depending on the response of the material, in a $40-60^{\circ} \mathrm{C}$ water bath. Prior to cleaning, visible pieces of rice paper were removed, and the glue was scraped off under the microscope. A piece of rice paper removed from the Temple scroll (Sample 9) was cleaned and dated to estimate the effect of this contaminant.

Papyrus samples (1st set) were chemically cleaned with $0.5 \mathrm{M} \mathrm{HCl}$ and $0.1 \mathrm{M} \mathrm{NaOH}$, at $40^{\circ} \mathrm{C}$ for $45 \mathrm{~min}$ for each step. The final acidification was done rapidly $(10 \mathrm{~min})$ with $0.05 \mathrm{M} \mathrm{HCl}$, because much of the material had already dissolved. To avoid similar dissolution of samples from the 2 nd set, these samples were treated with $0.25 \mathrm{M} \mathrm{HCl}, 0.05 \mathrm{M} \mathrm{NaOH}$ and $0.25 \mathrm{M} \mathrm{HCl}$, at $50^{\circ} \mathrm{C}$ for 40 min (for each step). The linen threads were cleaned using $0.5 \mathrm{M} \mathrm{HCl}, 0.1 \mathrm{M} \mathrm{NaOH}$ and $0.5 \mathrm{M} \mathrm{HCl}$ in a $40-60^{\circ} \mathrm{C}$ water bath, each step lasting $45 \mathrm{~min}$.

Following the chemical treatment, each sample was dried overnight in a $60^{\circ} \mathrm{C}$ oven. All of the remaining sample material, or up to $10 \mathrm{mg}$, was combusted in evacuated sealed quartz tubes, with copper oxide and silver wire. This lasted for $2 \mathrm{~h}$ at $950^{\circ} \mathrm{C}$. In the presence of hydrogen, the carbon dioxide was reduced to filamentous graphite over a cobalt catalyst, using the method described by Vogel et al. (1984) and Vogel, Southon and Nelson (1987). The resulting graphite-cobalt mixture was pressed onto copper targets for the measurement.

\section{MEASUREMENT, DATA EVALUATION AND CALIBRATION}

The ${ }^{14} \mathrm{C} /{ }^{12} \mathrm{C}$ and ${ }^{13} \mathrm{C} /{ }^{12} \mathrm{C}$ ratios were determined quasi-simultaneously and relative to the respective NBS oxalic acid I and PDB standard values (Bonani et al. 1987). The conventional radiocarbon ages were calculated using the procedure suggested by Stuiver and Polach (1977). They were corrected for natural fractionation and reported in years BP (before 1950). The results listed in Table 1 are the weighted mean values of at least two independent measurements of differently prepared subsamples. The errors quoted are at the one-sigma ( 1 o l level, and represent the statistical error of the mean or the variance, whichever is larger. 
The calibrated $1 \sigma^{14} \mathrm{C}$ age ranges (68\% confidence levels) are also listed in Table 1 . They were determined from the high-precision curve of Stuiver and Pearson (1986) based on dendrochronological dating. For this transformation, we used the CalibETH program (Niklaus et al. 1991) which calculates the probability distribution, as described by Stuiver \& Reimer (1987). No additional uncertainty has been added, assuming that the growth period of the papyrus and the lifetime of the animals, as well as the timespan between harvesting and writing, were short compared to the other errors involved. Because of the nature of the calibration curve, the procedure leads to double ranges in five cases. Table 1 gives the probability of finding the true age in 1 of the 2 age ranges.

\section{RESULTS AND DISCUSSION}

The specific dates of the date-bearing scrolls and the paleographically determined age ranges, given in Table 1, were disclosed to the participants at the Zürich AMS facility on!y after completion of the measurements. For ease of comparison, these data are displayed together with the calibrated, $1 \sigma{ }^{14} \mathrm{C}$ age ranges in Figure 2. The true ages of the four date-bearing manuscripts (Samples 1, 12, 13 and 14) lie within or close to the respective 1 o ranges. This indicates no significant methodological offset, either in the ${ }^{14} \mathrm{C}$ method or in the calibration curve based on measurements on American bristlecone pine and Irish oak trees. Good agreement between radiocarbon and paleographic dates is also observed in 9 of the remaining 10 samples. However, a slight systematic shift between the calibrated radiocarbon ages and the estimates of the paleographers might be inferred from the data. The calibrated ${ }^{14} \mathrm{C}$ ages are, on average, 35 years older. The statistical significance of this offset remains to be proven.

A discrepancy of approximately 200 years exists between the paleographical date and the calibrated radiocarbon dates of the Testament of Qahat (Sample 2 in Table 2). The calibrated radiocarbon

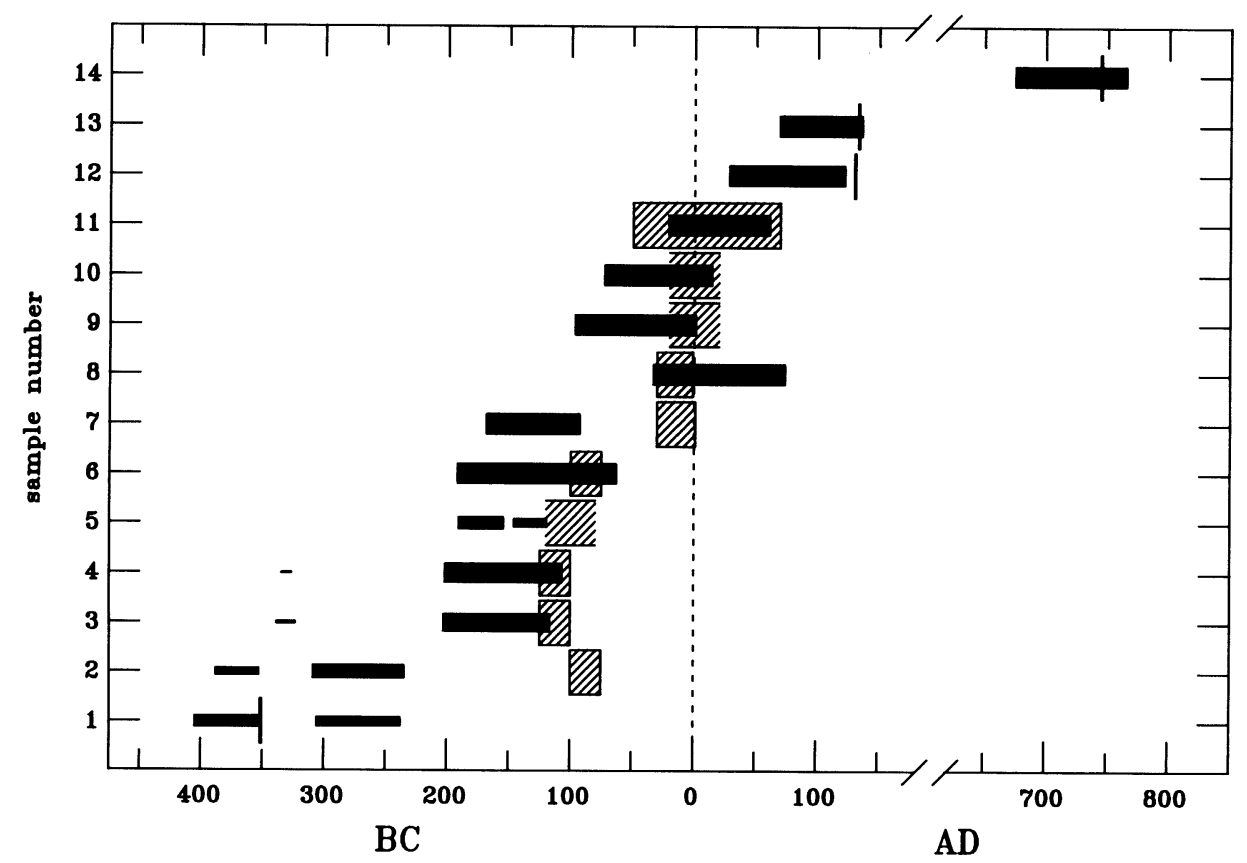

Fig. 2. Comparison of the calibrated $1 \sigma{ }^{14} \mathrm{C}$ ranges (horizontal black bars) with paleographical estimates (hatched areas) and specified dates (vertical lines). The thickness of the black bars is proportional to the probability to find the true age within the corresponding $1 \sigma$ range. Reprinted by permission of 'Atiqot; courtesy of Israel Antiquities Authority. 
TABLE 2. Comparison of ${ }^{14} \mathrm{C}$ results of solely ultrasonically and ultrasonically and chemically cleaned subsamples of the Qahat scroll

\begin{tabular}{ccc}
\hline & \multicolumn{2}{c}{${ }^{14} \mathrm{C}$ ages (yr BP) } \\
\cline { 2 - 3 } ETH no. & Ultrasonic & Ultrasonic and chemical \\
\hline $6640-1$ & $2605 \pm 48$ & \\
$6640-2$ & & $2340 \pm 49$ \\
$6640-4$ & & $2246 \pm 57$ \\
$7082-1$ & $2612 \pm 54$ & $2204 \pm 46$ \\
$7082-2$ & & $2158 \pm 55$ \\
$7082-4$ & & $2240 \pm 39$
\end{tabular}

date was determined from four chemically cleaned and independently measured samples. Paleographically, the Testament of Qahat has been ascribed a date of Late Hasmonean (Bonani et al. 1991). The possibility that the parchment was used for a second time (i.e., a palimpsest) can also be ruled out; infrared tests do not show evidence of earlier writing (Almog, personal communication 1990). It is also unlikely that the parchment was left unused for such a long period of time. However, in this case, it is difficult to rule out chemical contamination. Two separate samples, from distinct parts of the Qahat scroll, were taken at different times. In both cases, the samples that were only ultrasonically cleaned were approximately 350 years older than the samples that were ultrasonically and chemically cleaned (Table 2). Possible contaminants include castor oil (used, at one time, to improve the visibility of the writing), rice paper and glue. Castor oil and rice paper would yield younger apparent ages, as they contain modern carbon. On the other hand, the glue (a petroleum product) used to attach the rice paper to the scrolls would increase the apparent age of the scroll. Microscopic examination of the Qahat sample material did not reveal the presence of rice paper or glue; also, the parchment was ungelatinized. It is interesting to note that a sample of rice paper and glue removed from the Temple scroll (Sample 9) yielded an age of $6215 \pm 75$ BP. It should be emphasized that no similar age discrepancy was found between the solely ultrasonic and ultrasonic and chemically cleaned subsamples of the other 13 scrolls that were dated.

Parchment samples from the Temple, Genesis and Thanksgiving scrolls were visibly the most gelatinized of the scrolls that we investigated. The parchment material was uniformly dark brown and translucent. During the initial sampling, an attempt was made to obtain ungelatinized portions in addition to samples from gelatinized edges of these scrolls. Also, additional, fresher material was requested from the Temple scroll. Table 3 shows the results of dating gelatinized and ungelatinized

TABLE 3. Comparison of ${ }^{14} \mathrm{C}$ results of gelatinized and ungelatinized scroll samples

\begin{tabular}{cccl}
\hline ETH no. & $\mathrm{S}^{*}$ & Scroll & ${ }^{14} \mathrm{C}$ ages $(\mathrm{yr} \mathrm{BP})$ \\
\hline 6650 & 4 & Temple & $2024 \pm 49^{* *}$ \\
6811 & 1 & & $2066 \pm 78$ \\
6646 & 3 & Genesis & $2015 \pm 37$ \\
6647 & 1 & & $2004 \pm 65^{* *}$ \\
6648 & 3 & Thanksgiving & $2006 \pm 52^{* *}$ \\
6649 & 2 & & $1943 \pm 36$
\end{tabular}

* $\mathrm{S}=$ number of measured subsamples

** Gelatinized samples 
samples from the same scroll. It includes the weighted averages for chemically treated and solely ultrasonically cleaned subsamples, and shows that the results agree within the stated error. This indicates that gelatinization does not affect the ${ }^{14} \mathrm{C}$ age of the parchment.

\section{ACKNOWLEDGMENTS}

We thank Mr. A. Drori, head of the Antiquity Authority of Israel, for his help and support throughout the project. We gratefully acknowledge the assistance of Irka Hajdas during the sample preparation phase. Our thanks are due Dr. Y. Almog, Israeli Police Force Forensic Section, for conducting the infra-red tests. Part of this work was funded by the Paul Scherrer Institute, Villigen and the Swiss National Science Foundation.

\section{REFERENCES}

Avigad, N. 1958 The palaeography of the Dead Sea Scrolls and related documents. In Rabin, C. and Yadin, Y., eds., Aspects of the Dead Sea Scrolls (=Scripta Hierosolymitana IV). Magnes Press: 56-87.

Benoit, P., Milik, J. T. and de Vaux, R. 1961 Discoveries in the Judaen Desert, II. Oxford, Oxford University Press: 93-95.

Birnbaum, S. A. 1971 The Hebrew Scripts. Leiden, Paleographic: $127 \mathrm{p}$.

Bonani, G., Beer, J., Hofmann, H-J, Synal H-A, Wölfli, W., Pfleiderer, C., Kromer, B., Junghaus, C. and Münnich, K. O. 1987 Fractionation, precision and accuracy in ${ }^{14} \mathrm{C}$ and ${ }^{13} \mathrm{C}$ measurements. In Gove, $\mathrm{H}$. E., Litherland, A. E. and Elmore, D., eds., Proceedings of the 4th International Symposium on Accelerator Mass Spectrometry. Nuclear Instruments and Methods B29: 87-90.

Bonani, G., Broshi, M., Carmi, I., Ivy, S., Strugnell, J. and Wölfli, W. 1991 Radiocarbon dating of the Dead Sea Scrolls. 'Atiqot XX: 27-32.

Broshi, M. 1990 The Dead Sea Scrolls discovery and identification. Israel Museum Journal 9: 31-41.

Cross, F. M. 1961 The development of the Jewish scripts in the Bible and the ancient Near East, In Wright, G. E., ed., The Bible and the Ancient Near East. London, Routledge and Kegan Paul: 133-202.

Damon, P. E., Donahue, D. J., Gore, B. H., Hatheway, A. L., Jull, A. J. T., Linick, T. W., Sercel, P. J., Toolin, L. J., Bronk, C. R., Hall, E. T., Hedges, R. E. M. , Housley, R., Law, I. A., Perry, C., Bonani, G., Trumbore, S., Wölfli, W., Ambers, J. C., Bowman S. G. E., Leese, M. N. and Tite, M. S. 1989 Dating of the Shroud of Turin. Nature 337: 611-615.

Eisenman, R. 1983 Maccabees, Zadokites, Christians and Qumran. Leiden, Brill: 29-31.

Libby, W. F. 1951 Radiocarbon dates II. Science 114: 291-296.

Milik, J. T. 1959 Ten Years of Discovery in the Wilderness of Judea. London, SCM Press: 73 p.

Niklaus, T., Bonani, G., Simonius, M., Suter, M. and Wölfli, W. 1992 CalibETH: An interactive computer program for the calibration of radiocarbon dates. Radiocarbon, this issue.
Stuiver, M. and Polach, H. A. 1977 Discussion: Reporting of ${ }^{14} \mathrm{C}$ data. Radiocarbon 19(3): 355-363.

Stuiver, M. and Pearson, G. W. 1986 High-precision calibration of the radiocarbon time scale, AD 1950500 BC. In Stuiver, M. and Kra, R. S., eds., Proceedings of the 12 th International ${ }^{14} \mathrm{C}$ Conference. Radiocarbon 28(2B): 805-838.

Stuiver, M. and Reimer, P. J. 1987 User's Guide to the Program Calib and Display Rev 2.1: Quaternary Isotope Laboratory, University of Washington, Seattle.

Sukenik, E. L. 1948 Hidden Scrolls Preliminary Report. Jerusalem, Mossad Bialik (in Hebrew).

Suter, M., Balzer, R., Bonani, G., Hofmann, H. J., Morenzoni, E., Nessi, M., Wölfli, W., Andrée, M., Beer, J. and Oeschger, H. 1984 Precision measurements of ${ }^{14} \mathrm{C}$ in AMS - some results and prospects. In Wölfli, W., Polach, H. A. and Anderson, H. H., eds., Proceedings of the 3rd International Symposium on Accelerator Mass Spectrometry. Nuclear Instruments and Methods B5: 117-122.

Vogel, J. S., Southon, J. R. and Nelson, D. E. 1987 Catalyst and binder effects in the use of filamentous graphite for AMS. In Gove, H. E., Litherland, A. E. and Elmore, D., eds., Proceedings of the 4th International Symposium on Accelerator Mass Spectrometry. Nuclear Instruments and Methods B29: 50-56.

Vogel, J. S., Southon, J. R., Nelson, D. E. and Brown, T. A. 1984 Performance of catalytically condensed carbon for use in accelerator mass spectrometry. Nuclear Instruments and Methods B5: 289-293.

Weiner, S., Kustanovich, Z., Emanuel, G-A and Traub, W. 1980 Dead Sea Scroll parchments: Unfolding of the collagen molecules and racemization of aspartic acid. Nature 287(5785): 820-823.

Wölfli, W. 1987 Advances in accelerator mass spectrometry. In Gove, H. E., Litherland, A. E. and Elmore, D., eds., Proceedings of the 4th International Symposium on Accelerator Mass Spectrometry. Nuclear Instruments and Methods B29: 1-13.

Zeuner, F. E. 1969 Notes on Qumran. Palestine Exploration Quarterly 92: 27-36. 